\title{
PEMBUATAN APLIKASI DALAM MENGINTEGRASIKAN DATA KEUANGAN, DATA ORDER, DAN DATA STOK PADA UKM MOST BROTHERS DI DEPOK JAWA BARAT
}

\author{
Lasminiasih, Sartika, Ranti Putri Pratiwi \\ Manajemen, Fakultas Ekonomi, Universitas Gunadarma \\ lasminiasih@staff.gunadarma.ac.id, sartika@staff.gunadarma.ac.id , \\ ranti_putri@staff.gunadarma.ac.id
}

\begin{abstract}
Most Brothers are Small Medium Enterprise (SME) in the printing or canvass clothes, shirts, hat, bags and others in the city of Depok. Currently, Most Brothers is still using the system of recording financial data, order data, and stock data manually or not computerized. This research aims to propose the use of a system information such as application in integrating financial data, order data, and stock data. The method used in this research is descriptive qualitative by conducting observations and interviews directly. In making application, used design database desktop based MYSQL application. The output produced by this application is a simple financial report consisting of income statement and cash flow. There is also a order data report to complete consumer orders in structured and timely. As well as, report of stock data to find out the number of raw materials available.
\end{abstract}

Keywords: Information System, Application, Financial Report, Order Data, Stock Data, Small Medium Enterprises (SME)

\begin{abstract}
Abstrak
Most Brothers adalah Usaha Kecil Makro (UKM) dalam bidang percetakan atau sablon baju, kaos, topi, tas dan lain-lain di kota Depok. Saat ini, Most Brothers masih menggunakan sistem pencatatan data keuangan, data order, dan data stok secara manual atau belum terkomputerisasi. Penelitian ini bertujuan untuk mengusulkan pembuatan sistem informasi berupa aplikasi untuk mengintegrasikan data keuangan, data order, dan data stok. Metode yang digunakan dalam penelitian ini adalah deskriptif kualitatif dengan malakukan observasi dan wawancara secara langsung. Dalam pembuatan aplikasi, digunakan perancangan database berbasis desktop dengan aplikasi MySQL. Output yang dihasilkan aplikasi ini yaitu laporan keuangan sederhana yang terdiri dari laba rugi dan arus kas. Terdapat pula Laporan data order untuk menyelesaikan pesanan konsumen secara terstruktur dan tepat waktu. Serta, laporan data stok barang untuk mengetahui jumlah bahan baku produksi yang tersedia.
\end{abstract}

Kata Kunci: Sistem Informasi, Aplikasi, Laporan Keuangan, Data Order, Data Stok, Usaha Kecil Makro (UKM)

\section{PENDAHULUAN}

Menurut hasil penelitian Daud dan Valeria (2014) dan Hastoni dan David (2007), perusahaan memerlukan sistem berbasis komputer untuk meningkatkan kualitas informasi. Sistem informasi berbasis komputer terkait dengan integrasi data dan informasi. Menurut temuan penelitian Srivastava (2012), integrasi data dilakukan dengan menggabungkan berbagai teknologi informasi dan secara real time untuk menggambarkan situasi bisnis yang sebenarnya.

Menurut temuan penelitian Reddy, dkk (2009), sistem informasi dapat mendukung kegiatan perusahaan untuk menghasilkan informasi dengan mengintegrasikan data dan prosedur dalam berbagai sistem teknologi informasi 
di perusahaan, misalnya mengintegrasikan informasi akuntansi dalam melakukan pengambilan keputusan. Sistem Informasi Akuntansi dapat mendukung penyediaan data akuntansi dan keuangan serta informasi lainnya yang dapat diperoleh dari transaksi akuntansi rutin di perusahaan (Hastoni dan David, 2007). Sistem informasi yang digunakan sebagai sistem pengambilan keputusan umum, dapat diimplementasikan dengan merancang dan dilanjutkan dengan pembuatan aplikasi.

Penelitian ini memfokuskan pada salah satu Usaha Kecil Menengah (UKM) di kota Depok. Usaha Kecil Menengah (UKM) merupakan suatu entitas atau kelompok masyarakat dengan skala kecil dalam menjalankan usaha. Menurut Undang-Undang Republik Indonesia No.20 Tahun 2008 Usaha kecil adalah usaha produktif yang berdiri sendiri yang dilakukan oleh perorangan atau badan usaha yang bukan merupakan anak perusahaan atau bukan cabang perusahaan yang dimiliki dikuasai atau menjadi bagian baik langsung maupun tidak langsung dari usaha menengah atau usaha besar yang memenuhi kriteria usaha kecil. Sedangkan usaha menengah adalah usaha produktif yang berdiri sendiri yang dilakukan oleh perorangan atau badan usaha yang bukan merupakan anak perusahaan atau bukan cabang perusahaan yang dimiliki dikuasai atau menjadi bagian baik langsung maupun tidak langsung dari usaha kecil atau usaha besar dengan jumlah kekayaan bersih atau hasil penjualan tahunan sebagaimana diatur dalam undang-undang ini.

Penelitian ini dilakukan untuk membantu UKM Most Brothers dalam mengembangkan kegiatan usahanya. Hal ini dapat dilakukan dengan membangun sistem informasi yang dapat mengintegarsikan data penjualan, data order, dan data stok barang. Sehingga, penelitian ini melakukan pembuatan aplikasi untuk menghasilkan laporan data keuangan sederhana yang memberikan informasi keuangan dengan cepat dan akurat. Terdapat pula data order untuk menyelesaikan pesanan konsumen secara terstruktur dan tepat waktu. Serta, laporan data stok barang untuk mengetahui jumlah bahan baku produksi yang tersedia.

Penelitian memiliki beberapa sumber referensi utama yaitu sebagi berikut ini. Hasil penelitian yang dilakukan oleh Kurniawan dan Mario (2013) yaitu pengembangan sistem informasi berbasis web dapat membantu perusahaan untuk menyederhanakan urutan dan proses penjualan kepada pelanggan. Menurut Alim dan Haryanto (2008), melakukan perancangan dan pembuatan sistem informasi dapat mempermudah dalam memperoleh informasi dan aktivitas perusahaan secara mudah, cepat, dan akurat. Menurut Purnomo dan Toto (2002), penggunaan sistem informasi dapat memperoleh informasi penjualan dalam melakukan pengambilan keputusan pemasaran.

\section{METODE PELAKSANAAN}

Penelitian ini menggunakan metode diskriptif kualitatif yaitu dengan memperoleh data dan informasi secara rinci dengan melakukan observasi dan wawancara secara langsung kepada UKM Most Brothers di Kota Depok.

\section{Objek Penelitian}

Objek yang dipilih dalam penelitian ini yaitu Most Brothers yang merupakan UKM dalam bidang percetakan atau sablon baju, kaos, topi, tas dan lain-lain di Kota Depok. Penelitian ini tertarik dilakukan karena Most Brothers masih menggunakan sistem pencatatan data keuangan, data order, dan data stok secara manual atau belum terkomputerisasi. Sehingga, belum adanya sistem informasi yang terintegrasi antara data tersebut. 
Populasi dan Sampel Penelitian

Populasi dalam penelitian ini adalah pemilik dan karyawan UKM Most
Brothers yang dapat dilihat pada Tabel 1, sebagai berikut:

Tabel 1. Populasi Penelitian pada UKM Most Brothers

\begin{tabular}{|l|l|l|}
\hline \multicolumn{1}{|c|}{ No } & \multicolumn{1}{|c|}{ Jabatan } & Jumlah \\
\hline 1 & Pemilik (admin) & 1 \\
\hline 2 & Bagian Desain (user) & 1 \\
\hline 3 & Bagian Desain & 2 \\
\hline 4 & Bagian Produksi & 3 \\
\hline \multicolumn{2}{|c|}{ Sumber: Data Diproses (2018) } \\
\hline
\end{tabular}

Pada penelitian ini, sampel yang digunakan dapat dilihat pada Tabel 2, sebagai berikut:

Tabel 2. Sampel Penelitian pada UKM Most Brothers

\begin{tabular}{|l|l|l|}
\hline No & \multicolumn{1}{|c|}{ Jabatan } & Jumlah \\
\hline 1 & Pemilik atau Admin & 1 \\
\hline 2 & Bagian Desain dan User & 1 \\
\hline & Jumlah Populasi & $\mathbf{2}$ \\
\hline
\end{tabular}

Sumber: Data Diproses (2018)

\section{Variabel dan Data}

Penelitian ini menggunakan tiga variabel utama yaitu data keuangan, data order atau pesanan, dan data stok barang.

\section{Metode Pengumpulan Data}

Pengumpulan data dalam penelitian ini dilakukan menggunakan dua cara yaitu studi lapangan (observasi dan wawancara) dan studi literatur.

\section{Analisis Sistem Saat Ini}

UKM Most Brothers memiliki kendala utama yaitu data utama (data keuangan, data order, dan data stok) masih tercatat secara manual atau tidak terkomputerisasi.

\section{Metode Pengembangan Sistem Informasi}

Metode pengembangan sistem informasi pada penelitian ini dapat dilihat pada Gambar 1 di bawah ini :

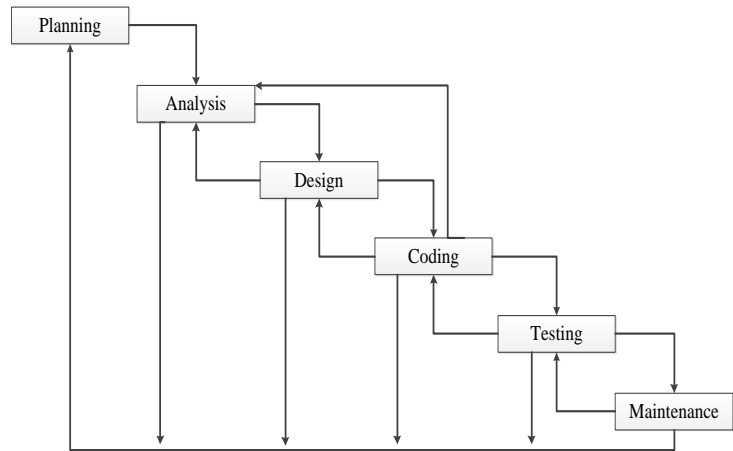

Gambar 1. Metode Pengembangan Sistem Informasi-Model Waterfall Sumber: Pressman (2003) 
Metode pengembangan sistem informasi yang digunakan adalah "Linear Sequential

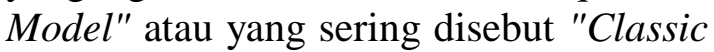
Life Cycle" atau model waterfall. Pada pendekatan ini bahwa setiap tahapan harus menunggu penyelesaian tahapan sebelumnya, berjalan secara berurutan, dan dari satu tahapan dapat kembali atau mundur ke tahapan sebelumnya.

\section{Bahasa Program}

Bahasa pemrograman yang digunakan dalam penelitian ini adalah
Structured Query Language (SQL) dan C\#.

\section{Tahap Penelitian}

Penelitian ini menggunakan dua metode pengumpulan data yaitu pengumpulan secara langsung pada UKM Most Brothers dan metode pengembangan sistem menggunakan model waterfall yang dapat dilihat pada Gambar 2 sebagai berikut:

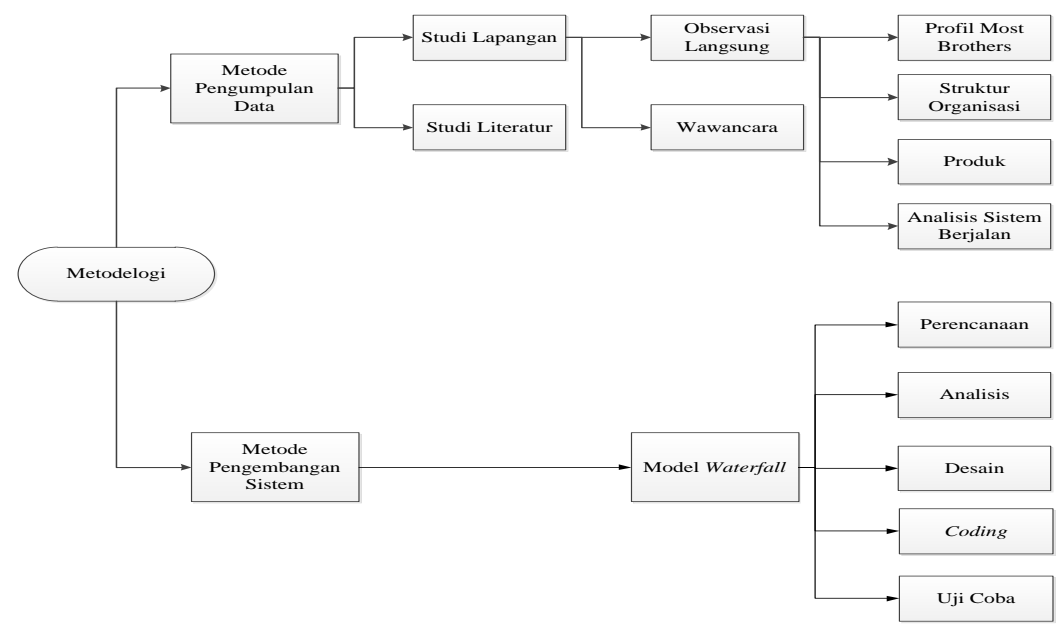

\section{Gambar 2. Tahap Penelitian}

Sumber: Data Diproses (2018)

Berdasarkan Gambar 2, teoritis dari masalah dan kebutuhan sistem menunjukkan bahwa tahap penelitian dilakukan dengan pengumpulan data melalui studi lapangan dan literatur untuk mengidentifikasi masalah di UKM Most Brothers. Studi lapangan dilakukan dalam bentuk observasi langsung dan wawancara kepada pihak yang berkepentingan di UKM Most Brothers. Observasi dan wawancara dilakukan agar penelitian ini dapat memperoleh gambaran umum Most Brothers dalam bentuk profil, struktur organisasi, produk, dan menganalisis sistem yang sedang berjalan. Hal itu juga dilakukan untuk mengetahui secara rinci mengenai masalah dan kebutuhan di Most Brothers. Selain sistem, penelitian juga mengacu pada studi literatur sebagai dasar yang diteliti.

Setelah metode pengumpulan data, selanjutnya adalah metode pengembangan sistem menggunakan model Waterfall. Model Waterfall terdiri dari enam tahap pengembangan sistem informasi yaitu sebagai berikut:

1. Tahap pertama yaitu perencanaan, pada tahap ini dilakukan pengamatan mengenai sistem informasi yang cocok untuk diterapkan. Hal ini dilakukan dengan cara mengobservasi langsung dan wawancara kepada pemilik dan karyawan Most Brothers.

2. Tahap kedua adalah analisis, pada tahap ini dilakukan analisis aplikasi data keuangan, data order, dan data 
stok barang yang sesuai dengan kebutuhan Most Brothers.

3. Tahap ketiga yaitu desain, pada tahap ini kebutuhan sistem informasi pada Most Brothers digambarkan dalam bentuk sistem"blue print" berupa desain antarmuka (design interface).

4. Tahap keempat adalah coding, desain yang telah dirancang akan diubah menjadi bahasa pemrograman atau menerjemahkan data ke dalam bahasa pemrograman yang dirancang agar dapat dipahami oleh mesin komputer. Bahasa pemrograman yang digunakan dalam penelitian ini adalah Structured Query Language (SQL) dan C\#.
5. Tahap lima adalah tahap uji coba, pada tahap ini end user akan diminta untuk mencoba aplikasi yang telah dibuat.

\section{HASIL DAN PEMBAHASAN}

Sistem informasi pada UKM Most Brothers masih relatif sangat sederhana dan belum terkomputerisasi. Pihak yang terlibat secara langsung dalam sistem informasi tersebut yaitu pemilik sebagai admin dan satu karyawan sebagai user. Sistem yang sedang berjalan pada Most Brothers terdiri dari tiga bagian utama yang dapat dilihat pada Gambar 3 berikut ini.

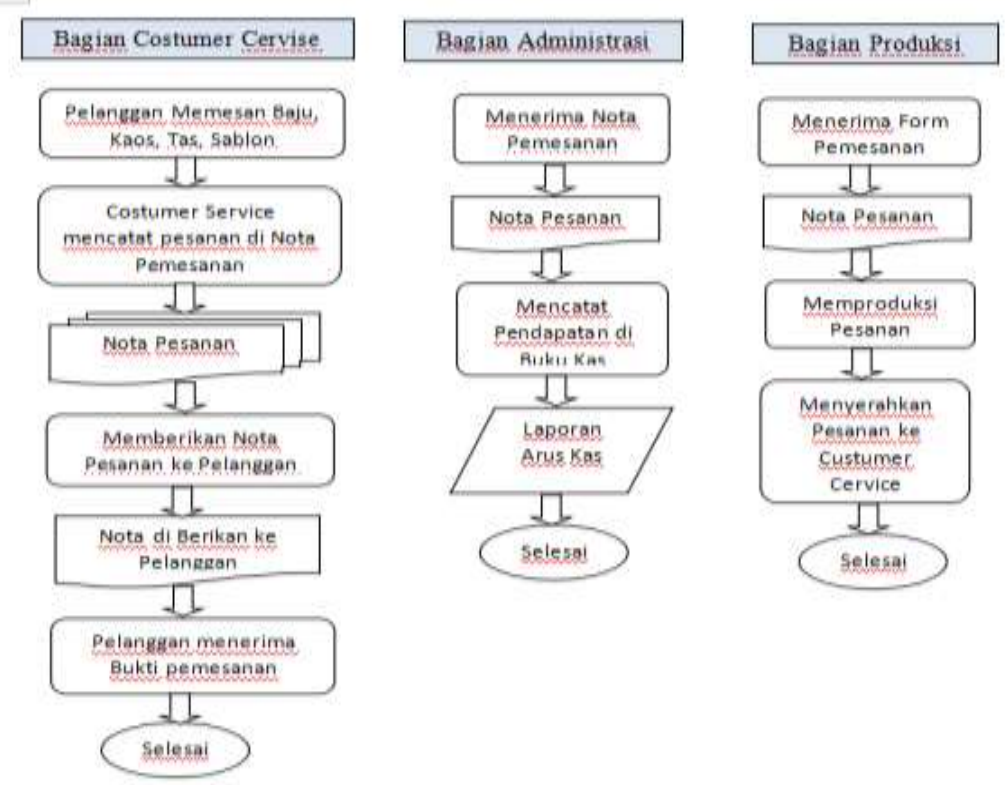

Gambar 3. Analisis Sistem Berjalan pada Most Brothers Sumber: Data Diproses (2018)

Berdasarkan Gambar 3, aktivitas utama Most Brother terdiri dari : Pertama, pemilik yang berperan sebagai customer service menangani konsumen dengan mencatat data order atau pesanan secara manual menggunakan nota tiga rangkap, selanjutnya, rangkap satu diberikan kepada konsumen, rangkap dua diberikan kepada bagian administrasi, dan rangkap tiga akan diberikan kepada bagian produksi. Kedua, apabila bagian admistrasi (admin) telah menerima nota order atau pesanan tersebut, maka admin mencatat pendapatan ke buku kas yang diproses menjadi laporan arus kas. Ketiga, setelah bagian produksi menerima nota order atau pesanan, karyawan ini langsung memproduksi pesanan dan menyerahkan pesanan yang telah selesai kepada customer service.Terdapat pula tambahan yaitu data stok barang untuk mengetahui jumlah bahan baku produksi dicatat secara manual oleh karyawan bagian produksi. 
Hal tersebut mengakibatkan data penting pada Most Brothers tidak terintegrasi, karena belum adanya sistem informasi yang terkomputerisasi. Padahal, data yang saling terintegrasi dapat menghasilkan output yang sangat bermanfaat bagi Most Brothers dalam melakukan pengambilan keputusan yang tepat. Most Brothers pula memiliki risiko kehilangan data dan ketidakuratan data yang sangat tinggi sebab data dicatat dalam nota tertulis dan buku catatan. Tentu, data tersebut menjadi rentan hilang, rusak dan terjadi kesalahan catat. Maka dapat disimpulkan bahwa kendala utama Most Brothers yaitu kumpulan data yang seharusnya menjadi informasi penting menjadi tidak fleksibel bagi pemilik dalam melakukan pengambilan keputusan. Selain itu, data yang disimpan menjadi tidak aman dari orang lain yang tidak memiliki hak untuk mengakses. Hal ini dapat mengakibatkan kesulitan pemilik untuk menelusuri penyebab terjadinya kesalahan data tersebut. Terdapat pula kendala lain yaitu belum adanya database yang terintegrasi, sehingga sulit untuk mengoptimalkan kinerja manajemen dan kinerja keuangan bisnis secara akurat.

Pemilik dan karyawan pada Most Brothers saat ini, masih mengalami kesulitan dalam mencari data dengan cepat karena data masih berupa nota dan buku catatan yang tidak terorganisir dengan baik. Selain itu, Most Brother pula belum memiliki format standar untuk data keuangan, data order, dan data stok. Tentu hal ini mengakibatkan kesulitan dalam membuat laporan yang berisi informasi penting seperti laporan laba rugi, laporan arus kas, laporan order, dan laporan stok barang.

\section{Usulan Pembuatan Aplikasi}

Berdasarkan analisis yang telah dilakukan, Most Brothers membutuhkan pembuatan aplikasi yang dapat mengintegrasikan data keuangan, data order, dan data stok. Integrasi data tersebut dapat menjadi solusi bagi pemilik Most Brothers untuk mengurangi risiko kesalahan yang sering terjadi seperti kesalahan pencatatan laporan laba-rugi dan arus kas. Selain itu, sering terjadi keterlambatan penanganan order dari konsumen dan kesalahan dalam penghitungan data stok barang. Pembuatan aplikasi diharapkan dapat membantu pemilik dalam melakukan pengambilan keputusan yang tepat. Berikut inibeberapa tahapan dalam pembuatan aplikasi pada Most Brothers.

\section{Desain antarmuka (Interface Design)}

Pembuatan desain antarmuka (interface design) bertujuan untuk mendeskripsikan desain tampilan yang baik dan mudah dipahami oleh pengguna. Selanjutnya yaitu dibutuhkan pembagian hak akses yang telah disesuaikan dengan kebutuhan Most Brothers. Untuk mempermudah dalam memahami aplikasi ini, maka berikut ini merupakan pembagian hak akses yang dimiliki.

\begin{tabular}{|c|c|c|c|}
\hline No & Keterangan & $\begin{array}{c}\text { Hak Akses Pemilik } \\
\text { (admin) }\end{array}$ & $\begin{array}{c}\text { Hak Akses } \\
\text { Karyawan } \\
\text { (user) }\end{array}$ \\
\hline 1 & Input Data Keuangan & $\begin{array}{l}\text { Tambah, Edit, dan } \\
\text { Hapus Data }\end{array}$ & Tambah Data \\
\hline 2 & Input Data Order & $\begin{array}{l}\text { Tambah, Edit, dan } \\
\text { Hapus Data }\end{array}$ & $\begin{array}{l}\text { Tambah dan } \\
\text { Edit Data }\end{array}$ \\
\hline 3 & Input Data Stok & $\begin{array}{l}\text { Tambah, Edit, dan } \\
\text { Hapus Data }\end{array}$ & $\begin{array}{l}\text { Tambah dan } \\
\text { Edit Data }\end{array}$ \\
\hline
\end{tabular}




\begin{tabular}{llll}
\hline $\mathbf{4}$ & $\begin{array}{l}\text { Output Laporan Laba Rugi } \\
\text { dan Arus Kas }\end{array}$ & Dapat Mengakses & $\begin{array}{l}\text { Tidak Dapat } \\
\text { Mengakses }\end{array}$ \\
\hline $\mathbf{5}$ & Output Faktur Order & Dapat Mengakses & $\begin{array}{l}\text { Dapat } \\
\text { Mengakses }\end{array}$ \\
\hline $\mathbf{6}$ & $\begin{array}{l}\text { Output Laporan Stok } \\
\text { Barang }\end{array}$ & Dapat Mengakses & $\begin{array}{l}\text { Dapat } \\
\text { Mengakses }\end{array}$ \\
\hline
\end{tabular}

Berdasarkan Tabel di atas, aplikasi ini dibuat untuk dua pengguna utama yaitu pemilik sebagai admin yang diberikan hak akses penuh ke sistem secara keseluruhan. Selain itu, terdapat satu karyawan yang bertugas sebagai user yang memiliki hak akses terbatas. Most Brother merupakan UKM yang hanya memiliki enam orang karyawan dan usaha ini masih dikendalikan secara penuh oleh satu orang pemilik. Maka aplikasi ini pula bertujuan untuk mempermudah pekerjaan pemilik Most Brothers dengan adanya pembagian hak akses. Aplikasi ini pula data digunakan oleh lebih dari dua pengguna dengan hak akses masing-masing yang dapat disesuaikan dengan kebutuhan.

\section{Implementasi Sistem}

Pembuatan aplikasi pada Most Brothers ini menggunakan bahasa pemrograman Structured Query Language (SQL) dan C\#. Bahasa pemrograman merupakan tahapan menerjemahkan data ke dalam bahasa pemrograman yang dirancang agar dapat dipahami oleh mesin komputer.

Dalam pembuatan aplikasi, digunakan perancangan database berbasis desktop dengan aplikasi MySQL. Aplikasi ini dapat dijalankan di web browser yang hanya dilakukan secara offline. Perangkat lunak server web yang digunakan adalah menggunakan implementasi XAMPP v3.2.2. Dapat disimpulkan bahwa aplikasi ini berbasis desktop atau bersifat offline berdasarkan kebutuhan dari pemilik Most Brothers. Berikut ini adalah gambar Implementasi penggunaan aplikasi sistem pembukuan dapat dilihat pada gambar di bawah ini.

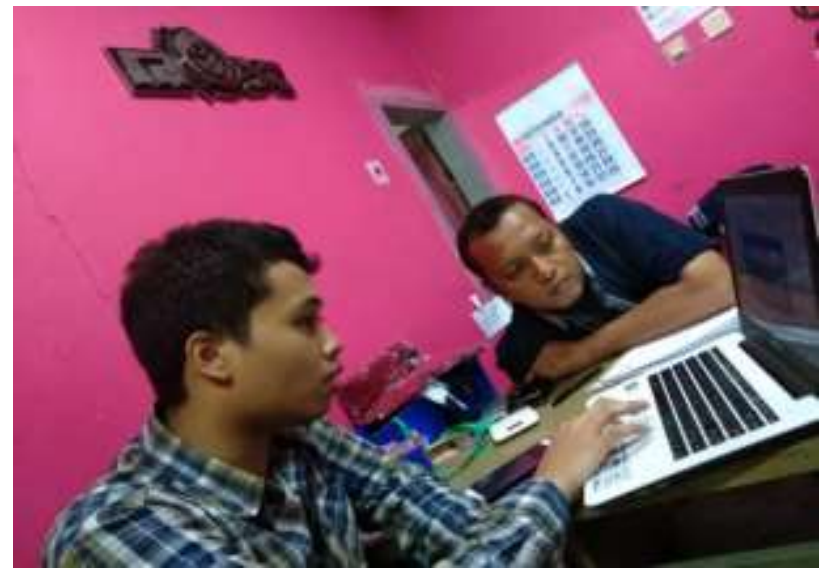

\section{Gambar 4. Implementasi Aplikasi Pembukuan Kepada UKM}

Gambar 4 merupakan implementasi penggunaan aplikasi pembukuan yang sudah dirancang dan siap untuk digunakan oleh UKM Most Brothers.
Uji Kelayakan Aplikasi

Untuk menentukan apakah aplikasi ini sesuai dengan kebutuhan Most Brothers, maka dilakukan uji kelayakan aplikasi menggunakan kuesioner. Kuesioner disampaikan kepada pengguna 
yang secara langsung berinteraksi dengan sistem ini yaitu pemilik (admin), satu karyawan (user), dan lima karyawan lainnya sebagai sampel tambahan. Pengisian kuesioner dimaksudkan untuk membandingkan antara sistem yang sedang berjalan dengan aplikasi ini. Untuk membandingkan kedua hal tersebut, digunakan beberapa aspek pengukuran kualitas terdiri dari kegunaan (usability), integritas data (data integrity), efisiensi (efficiency), dan kebenaran (correctness). Berdasarkan hasil kuesioner tersebut, dua pengguna utama (pemilik dan user) serta lima karyawan lainnya lebih memilih menggunakan aplikasi yang diusulkan pada penelitian ini dibandingkan sistem manual yang sedang berjalan. Berikut ini merupakan tampilan aplikasi yang diusulkan untuk Most Brothers sebagai berikut:

\section{Tampilan Login}

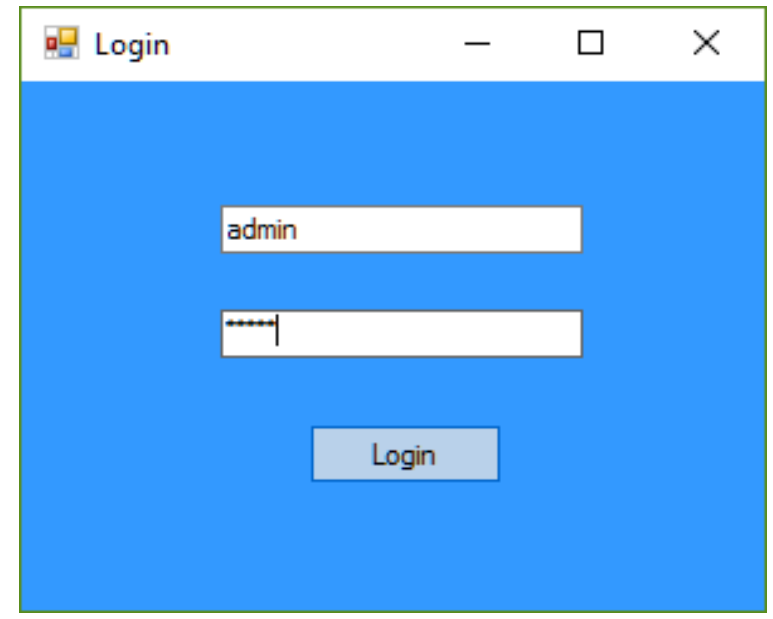

Gambar 4. Tampilan Login

Sumber: Data Diproses (2018)

Berdasarkan Gambar 4, form pada tampilan ini hanya dapat diisi oleh pengguna yang telah memiliki hak akses untuk masuk ke sistem. Pengguna utama pada aplikasi ini yaitu pemilik (admin) yang diberikan hak akses penuh ke sistem database secara keseluruhan. Selain itu, terdapat satu karyawan yang bertugas sebagai user yang memiliki hak akses terbatas. Most Brother merupakan UKM yang hanya memiliki 6 orang karyawan dan usaha ini masih dikendalikan secara penuh oleh pemilik. Aplikasi ini pula dapat digunakan oleh lebih dari dua pengguna dengan hak akses masingmasing yang dapat disesuaikan dengan kebutuhan dari pemilik.

Saat login, pengguna dapat memasukkan nama pengguna dan kata sandi ke dalam aplikasi kemudian dapat memilih Login. Jika proses masuk berhasil, pengguna akan dapat mengakses setiap halaman yang telah disesuaikan dengan hak akses masing-masing. Pada aplikasi ini juga terdapat tampilan informasi mengenai daftar pengguna yang memiliki hak akses pada aplikasi ini. 


\section{Pemberitahuan Mengenai Data Order}

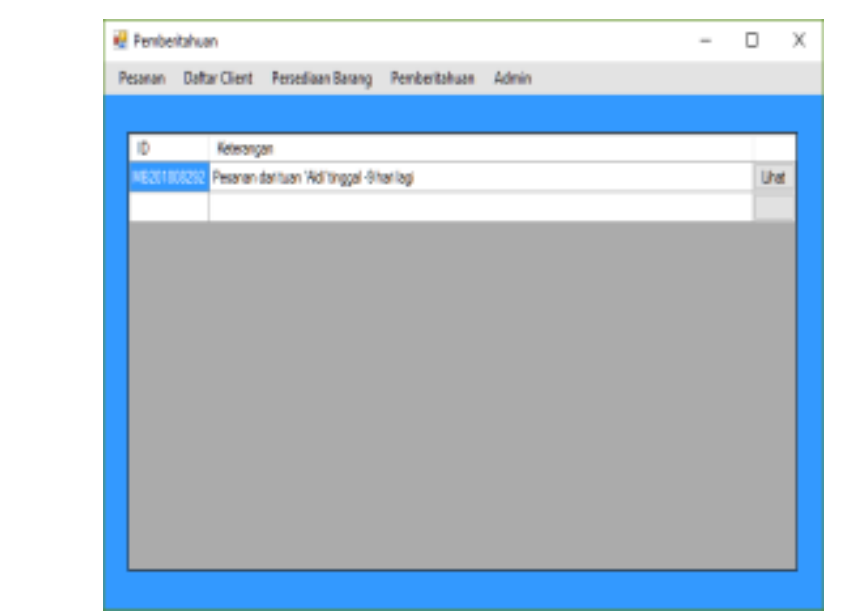

\section{Gambar 5. Pemberitahuan Mengenai Data Order Sumber: Data Diproses (2018)}

Gambar 5 di atas merupakan menu tampilan awal setelah melakukan login. Hal ini merupakan solusi dari salah satu kendala Most Brothers yaitu kesulitan dalam mengatur urutan produk mana saja yang harus didahulukan untuk dikerjakan agar dapat diselesaikan tepat waktu. Data pemberitahuan ini sebelumnya telah diinput oleh pemilik (admin) dan satu karyawan (user) yang telah diberikan hak akses. Mengklik Lihat yang yang berada di kanan atas berfungsi untuk melihat secara detail mengenai data order atau pesanan dari konsumen atau informasi berupa peringatan sisa waktu untuk melakukan penyelesaian pesanan tersebut.

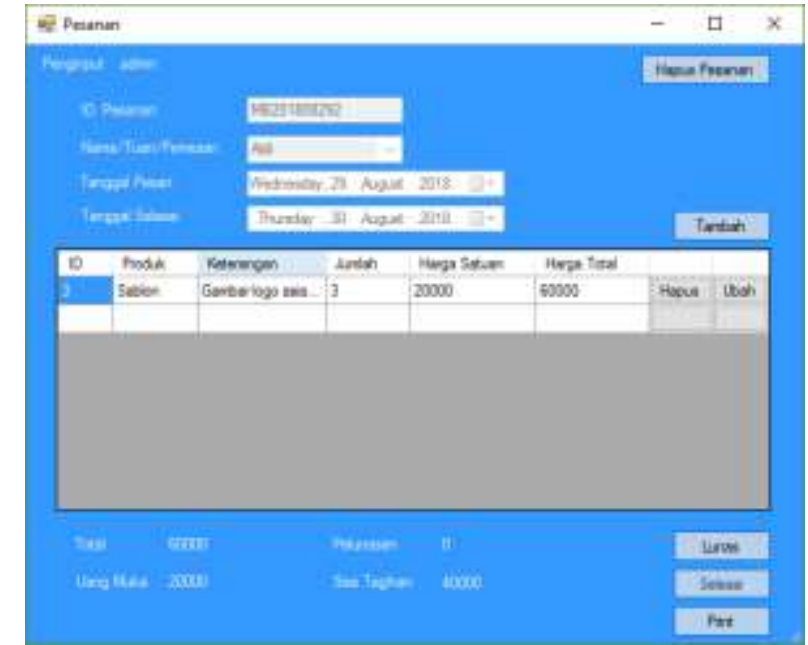

Gambar 6. Rincian Pemberitahuan Data Order Sumber: Data Diproses (2018)

Setelah mengklik Lihat pada tampilan Gambar 5 sebelumnya, maka akan muncul tampilan seperti Gambar 6 yang merupakan rincian pemberitahuan data order atau pesanan berupa produk apa yang dipesan oleh konsumen, keterangan pesanan, jumlah pesanan, harga satuan pesanan dan harga total. 


\section{Input Data Order}

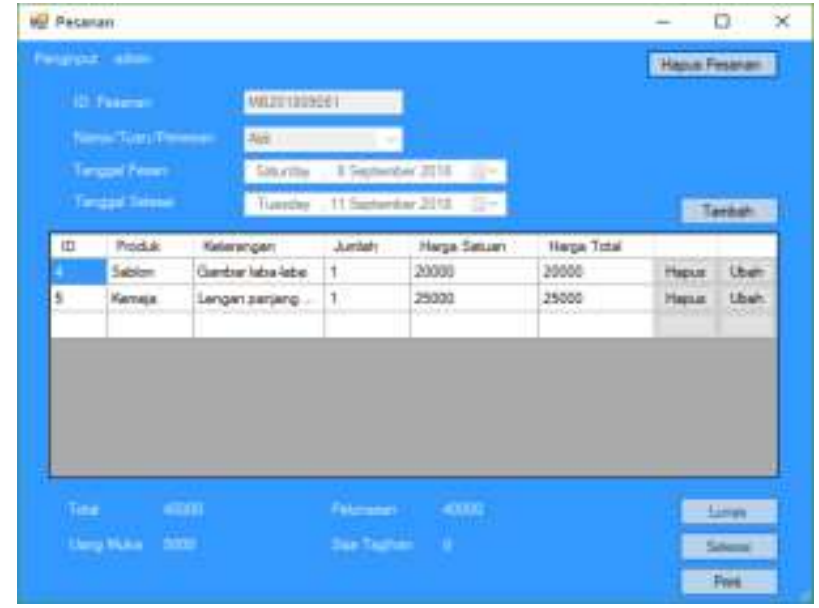

Gambar 7. Input Data Order

Sumber: Data Diproses (2018)

Berdasarkan Gambar 7 diatas, berikut ini tampilan data order atau input pesanan dari konsumen. Ketika konsumen melakukan order atau pesanan maka pemilik (admin) dan karyawan (user) menginput data yang dibutuhkan untuk dapat menghasilkan output berupa faktur. Data yang diinput pada menu order atau pesanan ini yaitu berupa nama pemesan, tanggal pesan, tanggal produk akan diselesaikan, jumlah uang muka dari konsumen, data produk (jenis produk, keterangan, harga satuan, dan harga total), dan pelunasan uang muka. Selanjutnya, apabila di klik Print maka akan muncul faktur pemesanan berdasarkan data order yang telah diinput.

\section{Faktur Data Order}

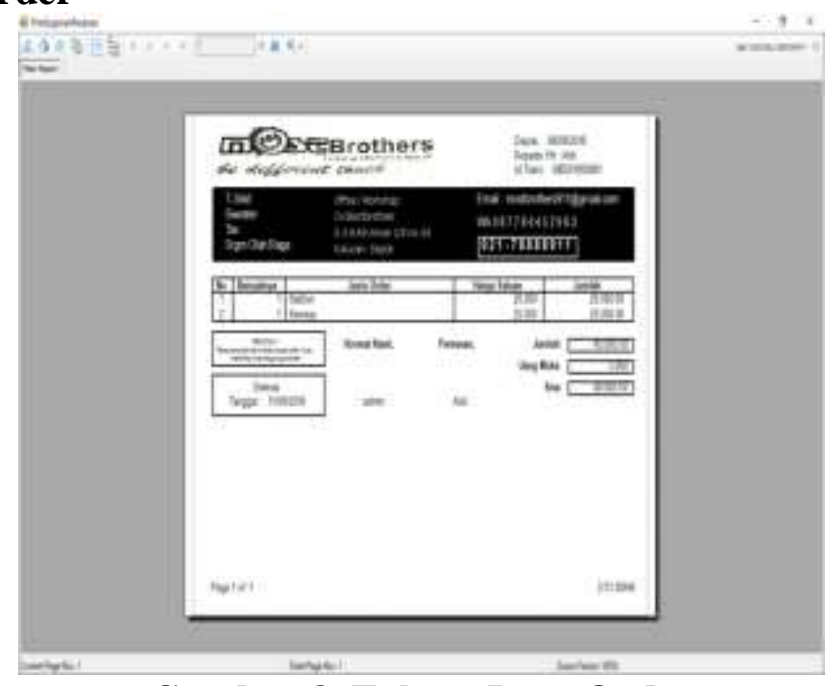

Gambar 8. Faktur Data Order

Sumber: Data Diproses (2018)

Gambar 8 di atas merupakan output dari data order yang sebelumnya telah diinput, faktur ini di print dan diberikan kepada konsumen sebagai bukti order serta pembayaran uang muka. Selain bukti pembayaran, pada faktur pula 
dirincikan mengenai produk dan jumlah yang dipesan. Tentunya informasi ini dibutuhkan untuk karyawan pada bagian produksi.

\section{Daftar Data Order}

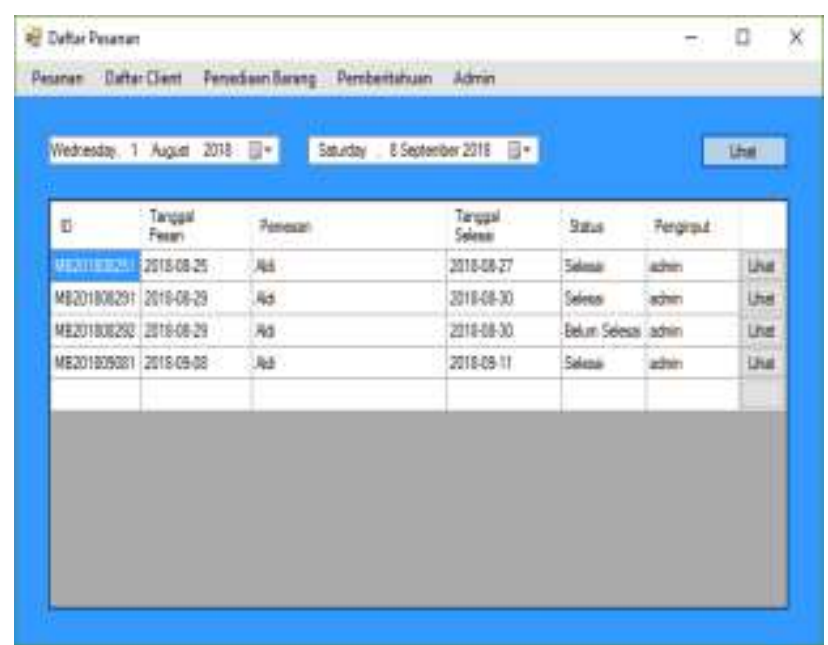

Gambar 9. Daftar Data Order

Sumber: Data Diproses (2018)

Gambar 9 di atas merupakan daftar data order atau pesanan yang dapat di lihat berdasarkan periode tanggal yang disesuaikan. Tentunya, data ini dapat mempermudah pekerjaan pada karyawan bagian produksi dalam hal menentukan prioritas mana yang harus dikerjakan terlebih dahulu. Selain itu, karyawan bagian produksi dapat mengecek ulang pekerjaan yang sudah dan belum diselesaikan. Selanjutnya, untuk melihat rincian order atau pesanan pada daftar pesanan maka dapat mengklik Lihat pada sisi kanan kolom.

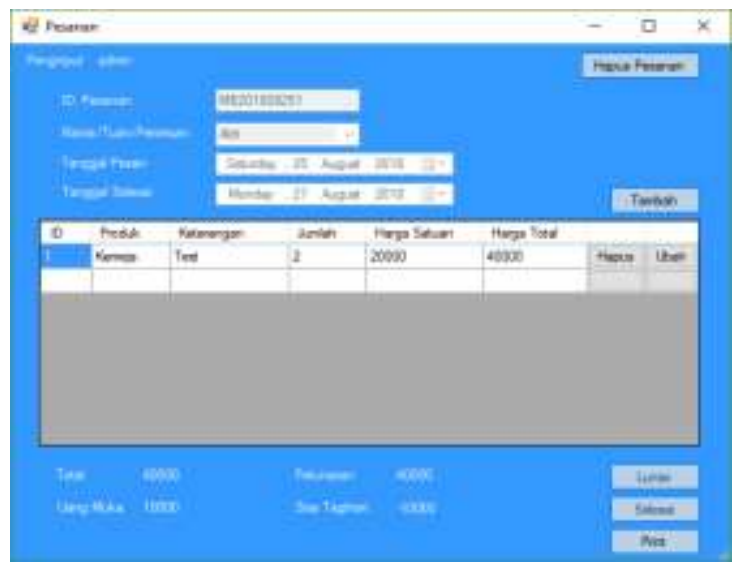

Gambar 10. Rincian Order

Sumber: Data Diproses (2018)

Setelah mengklik Lihat pada tampilan sebelumnya, maka akan muncul tampilan seperti pada Gambar 9 di atas berupa rincian order atau pesanan. Informasi pada menu ini terdiri dari nama pemesan, tanggal pesanan, tanggal selesai, no ID pesanan, nama produk, keterangan produk (jumlah pesanan, harga satuan, total harga, uang muka dan sisa tagihan). Selain itu, penguna juga dapat mengubah 
isi atau menghapus pesanan jika memang terjadi perubahan dari konsumen.

berfungsi menambahkan order atau Dilengkapi pula menu Tambah yang

pesanan oleh konsumen.

\section{Data Konsumen (Client)}

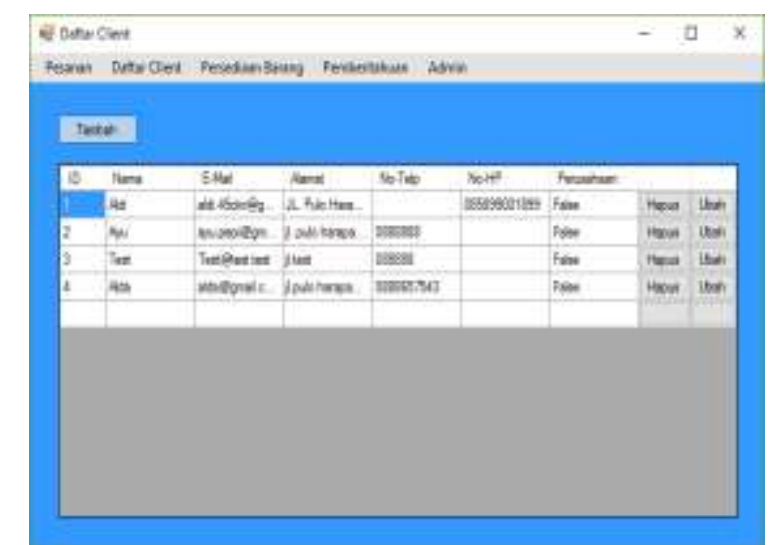

Gambar 11. Daftar Data Konsumen (Client) Sumber: Data Diproses (2018)

Gambar 11 di atas merupakan daftar data konsumen (client) yang pernah melakukan order atau pesanan. Tentunya, nenu Daftar Client ini dibutuhkan oleh Most Brothers sebagai database untuk dapat menjalin komunikasi yang baik terhadap konsumen. Selain itu, dapat membantu pemilik dalam pengambilan keputusan mengenai pangsa pasar, produk yang diminati, menentukan promo yang tepat bagi konsumen dll. Penguna pula dapat menambahkan konsumen (client) baru ke dalam database dengan cara mengklik menu Tambah. Selain itu, terdapat pula menu Hapus untuk menghapus konsumen (client) dari database dan menu Ubah untuk mengubah data client yang sudah terdaftar.

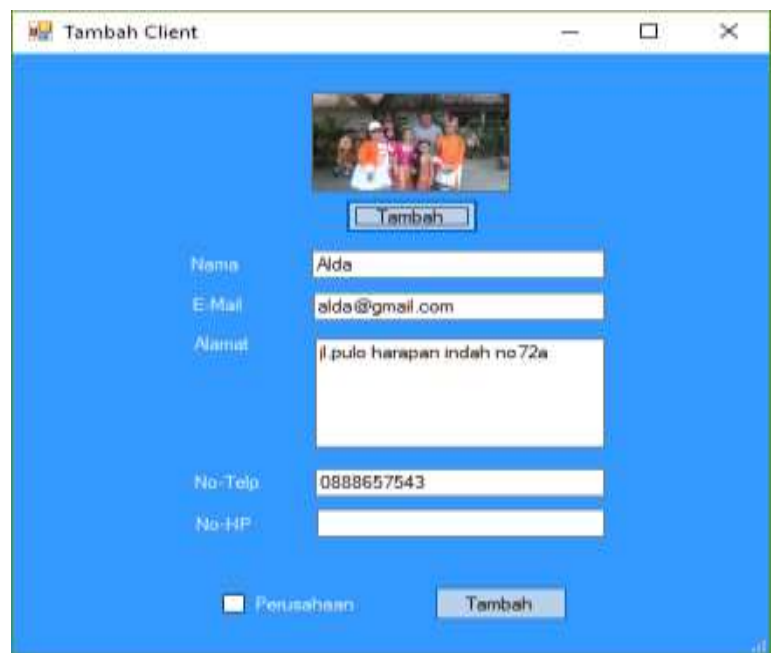

Gambar 12. Input Data Konsumen (Client) Sumber: Data Diproses (2018)

Setelah mengklik menu Tambah pada Gambar 11 sebelumnya, maka pengguna dapat melakukan input data konsumen (client) baru ke dalam database 
yang dapat dilihat pada Gambar 12 di atas. Pada Tampilan Tambah client ini, penguna dapat mengisi informasi mengenai nama konsumen (client), email, alamat, nomor telepon, dan nomor hp.
Tentunya, informasi ini diperlukan untuk mempermudah pengguna berkomunikasi atau menghubungi konsumen (client) tersebut.

\section{Stok atau Persediaan Barang}

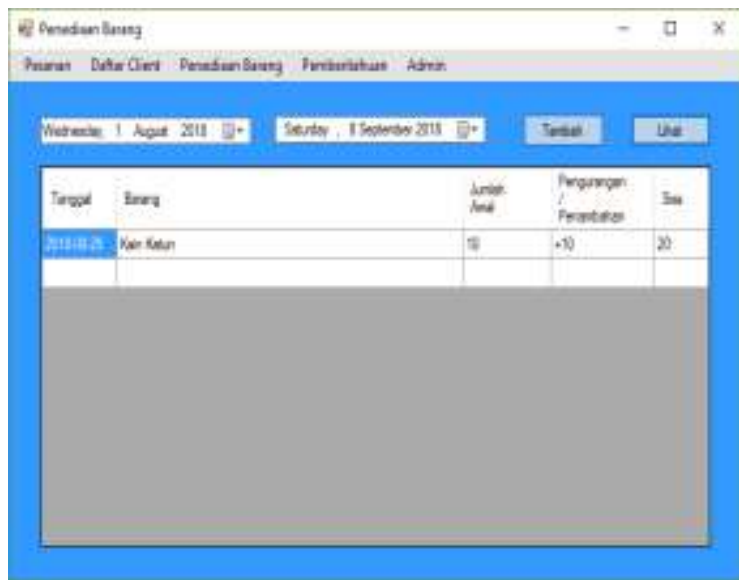

\section{Gambar 13. Daftar Stok atau Persediaan Barang}

Sumber: Data Diproses (2018)

Menu stok atau persedian barang yang terlihat pada Gambar 13, digunakan untuk melakukan pengecekan terhadap bahan baku yang digunakan dalam proses produksi. Selain itu, untuk mengetahui jumlah bahan baku yang digunakan untuk memproduksi sablon baju, kaos, topi, tas dll. Menu ini berisikan data barang atau bahan baku dalam proses produksi berupa tanggal, nama barang, jumlah awal barang, pengurangan / penambahan barang dan sisa barang.
Pada menu ini, penguna dapat mengecek stok atau persediaan barang sesuai dengan periode tanggal yang diinginkan. Dalam tampilan ini, terdapat menu Tambah dan menu Lihat. Menu Tambah digunakan untuk menambahkan stok atau persediaan barang, sedangkan menu Lihat digunakan untuk menampilkan stok atau persedian barang pada periode tanggal yang dapat disesuaikan.

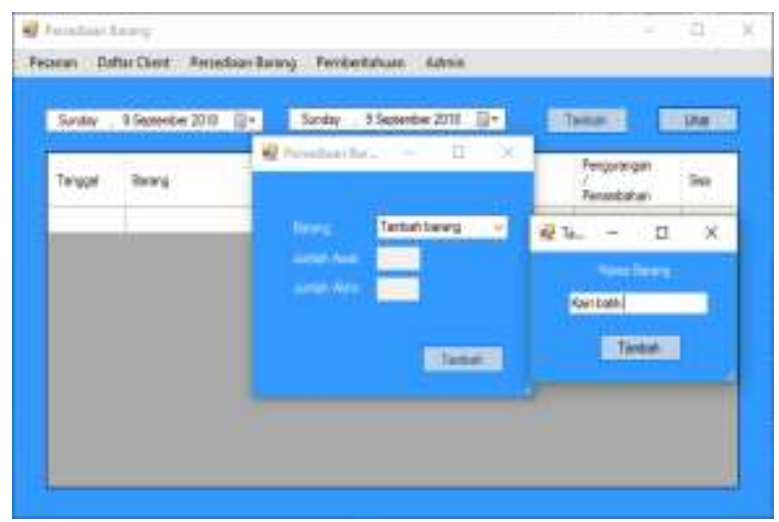

\section{Gambar 14. Input Stok atau Persediaan Barang Baru Sumber: Data Diproses (2018)}


Berdasarkan Gambar 14, tampilan ini muncul setelah mengklik menu Tambah yang berfungsi untuk menambahkan stok atau persediaan barang berupa bahan baku yang tersedia. Lalu, pilih Barang pada form yang tersedia, namun jika persedian barang tidak terdapat didalam list, maka pengguna dapat menambahkan bahan baku tersebut dengan mengklik Tambah Barang. Selanjutnya, akan muncul form Tambah Barang Baru dan pengguna dapat menginput Nama Barang tambahan pada form tersebut.

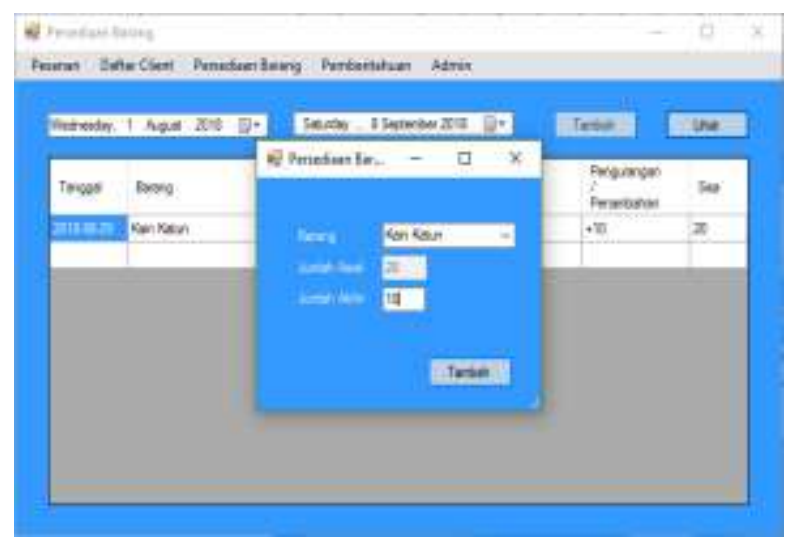

Gambar 15. Input Jumlah Stok atau Persediaan Barang Sumber: Data Diproses (2018)

Gambar 15 di atas merupakan tampilan untuk menginput atau mengupdate jumlah stok atau persediaan barang berupa bahan baku yang ada saat ini.
Setelah diisi, maka secara otomatis aplikasi akan mengakumulasi penambahan atau pengurangan terhadap bahan baku tersebut.

\section{Data Pengeluaran Biaya}

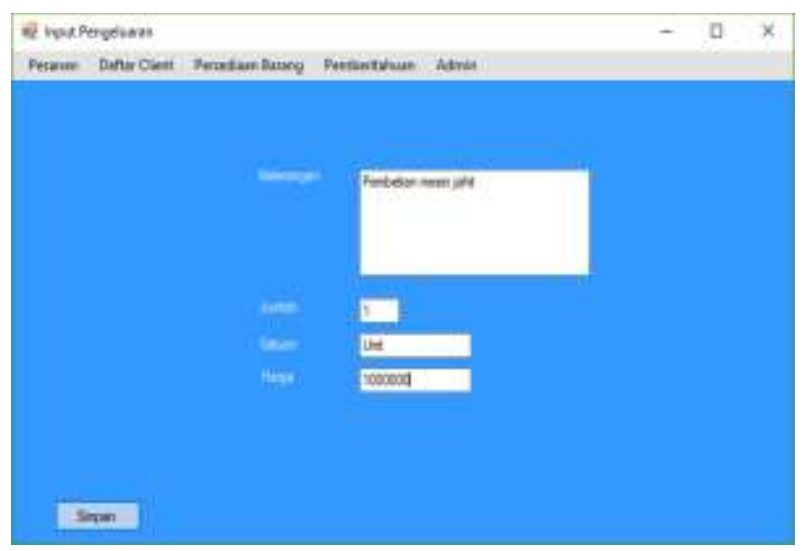

Gambar 16. Input Data Pengeluaran Biaya Sumber: Data Diproses (2018)

Berdasarkan Gambar 16, data pengeluaran biaya yang merupakan bagian dari data keuangan dapat diinput oleh pemilik (admin) dan user (karyawan). Namun untuk mengedit dan menghapus data, hak akses hanya dimiliki oleh pemilik (admin) untuk menghindari risiko kecurangan dan kesalahan yang 
dilakukan oleh karyawan. Pada tampilan ini, data yang di input berupa keterangan barang / jasa apa yang dibeli, jumlah barang/jasa, satuan, dan harga

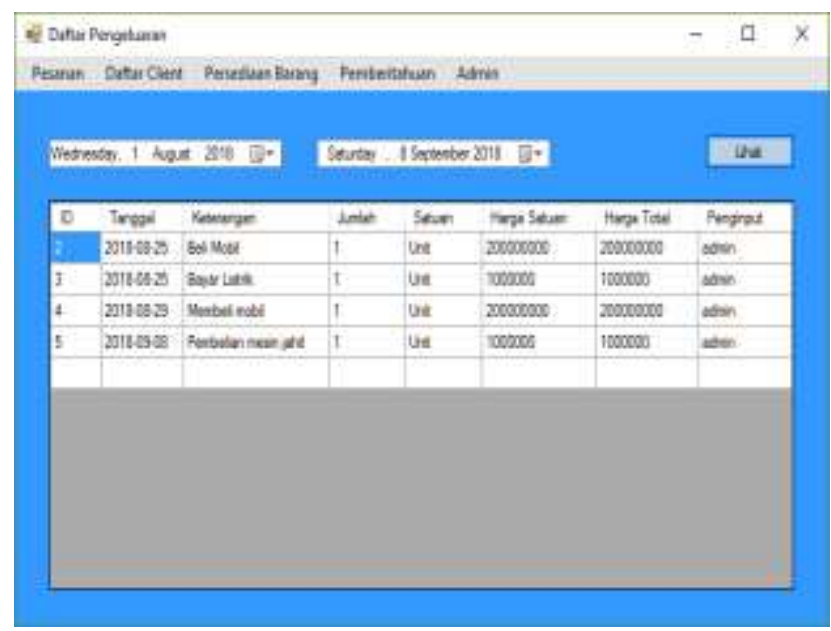

Gambar 17. Daftar Pengeluaran Biaya Sumber: Data Diproses (2018)

Setelah data pengeluaran biaya di input, maka dapat dilihat pada Gambar 17 berupa daftar pengeluaran biaya berdasarkan periode tanggal yang dapat disesuaikan. Tentunya, data pengeluaran biaya ini akan terintegrasi dengan data keuangan lainnya untuk dapat menghasilkan output berupa laporan laba rugi dan arus kas. Terdapat pula keterangan Penginput pada kolom di sisi kiri, hal ini dilakukan agar pemilik mengetahui siapa yang melakukan input, mengurangi kesalahan, dan data menjadi sulit dimanipulasi.

\section{Laporan Keuangan}

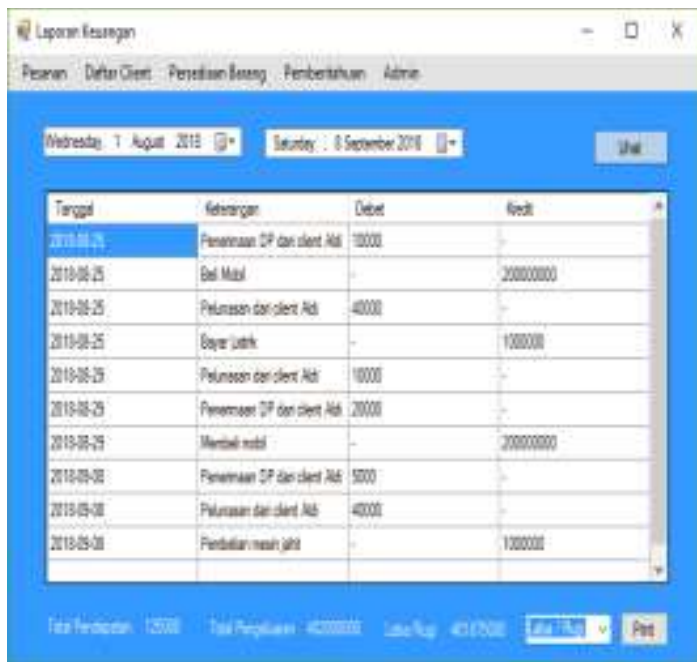

\section{Gambar 18. Data Penerimaan dan Pengeluaran} Sumber: Data Diproses (2018)

Tampilan Gambar 18 di atas merupakan bagian dari menu Admin lalu pilih Laporan Keuangan. Tampilan data penerimaan dan pengeluran dapat membantu pemilik (admin) untuk meringkas laporan keuangan berdasarkan 
periode tanggal yang dapat disesuaikan. Melalui Laporan Keuangan, pemilik dapat membandingkan kondisi finansial, misalnya pada periode bulan ini dengan bulan lalu. Sehingga mempermudah pemilik dalam mengambil keputusan atau tindakan yang diperlukan untuk kepentingan bisnisnya.
Data pada tampilan ini hanya bisa diakses oleh pemilik (admin) saja, karena sifatnya krusial dan tidak untuk dipublikasikan kepada karyawan. Pemilik (admin) dapat melakukan Print laporan yang berada sisi bawah kanan yang terdiri dari dua pilihan yaitu Laporan Laba Rugi atau Laporan Arus Kas.

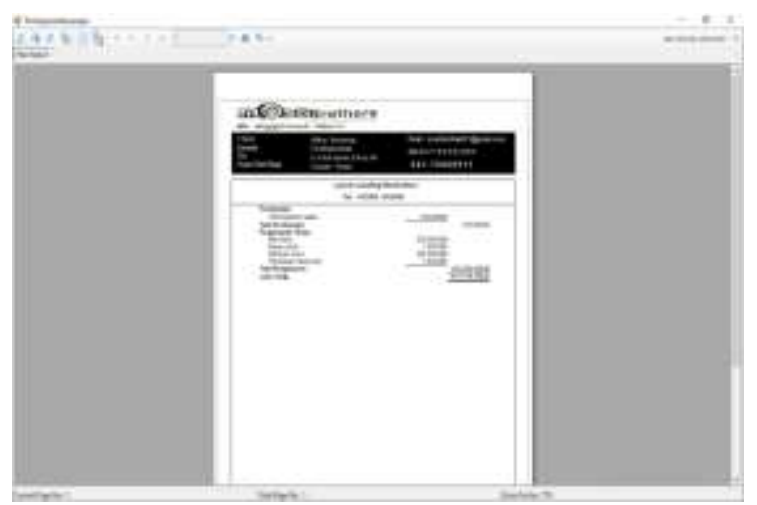

Gambar 19. Laporan Laba Rugi Sumber: Data Diproses (2018)

Tampilan Gambar 19 di atas merupakan hasil print laporan laba rugi yang terdiri dari penerimaan dan pengeluaran. Laporan laba rugi sangat bermanfaat bagi pemilik (admin) untuk mengetahui posisi keuangannya, apakah mengalami keuntungan atau kerugian. Sehingga, pemilik (admin) dapat melakukan pengambilan keputusan yang tepat. Tentunya, Laporan ini merupakan hasil dari integrasi data yang akurat, sulit dimanipulasi, dan memiliki tingkat kesalahan data yang rendah.

Pada laporan laba/rugi ini, digunakan metode single step atau cara langsung yaitu seluruh pendapatan dikelompokan kemudian dijumlahkan lalu menguranginya dengan total beban yang terjadi pada periode berjalan. Hal ini dilakukan atas permintaan pemilik untuk memperoleh laporan keuangan yang sederhana dan mudah dipahami

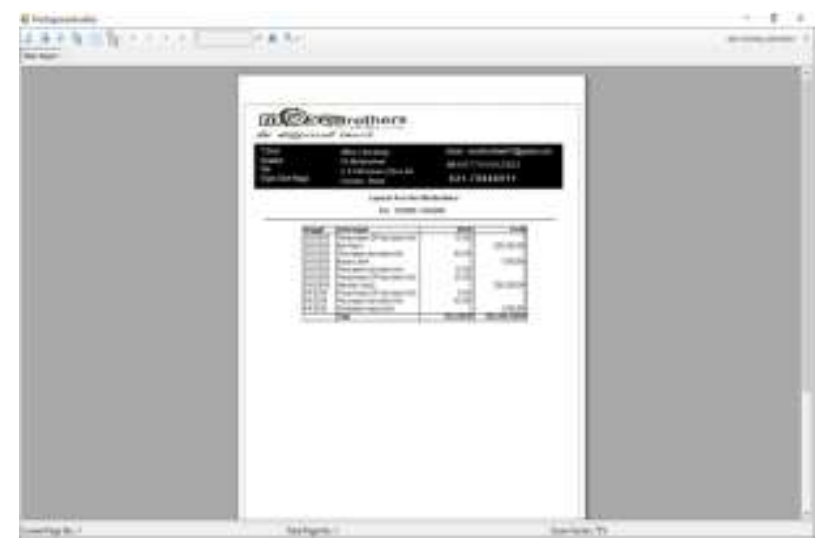

Gambar 20. Laporan Arus Kas

Sumber: Data Diproses (2018) 
Gambar 20 di atas merupakan output berupa laporan arus kas Most Brothers yang hanya dapat diakses oleh pemilik (admin) saja. Laporan arus kas bertujuan untuk menunjukkan data tentang aliran kas masuk dan keluar pada periode tertentu. Laporan arus kas ini merupakan salah satu alat untuk menentukan kebijakan pemakaian kas di periode berikutnya. Berdasarkan permintaan pemilik, arus kas ini dibuat sederhana dan mudah dipahami yaitu dengan menjumlahkan arus kas masuk masuk dan mengurangkan dengan jumlah arus kas keluar.

\section{PENUTUP}

Berdasarkan penelitian yang telah dilakukan, Usaha Kecil Makro (UKM) Most Brothers masih menggunakan sistem pencatatan data keuangan, data order, dan data stok secara manual atau belum terkomputerisasi. Hal tersebut menyebabkan Most Brothers mengalami beberapa kendala sebagai berikut. Pertama, belum adanya database yang terintegrasi. Kedua yaitu risiko kehilangan data, data yang rusak, dan ketidakuratan data yang sangat tinggi. Ketiga, data yang disimpan menjadi tidak aman dari orang lain yang tidak seharusnya memiliki hak akses. Keempat, kesulitan dalam mencari data dengan cepat karena data masih berupa nota dan buku catatan yang tidak terorganisir dengan baik. Kelima, belum memiliki format standar dalam data keuangan, data order, dan data stok. Keenam, tingginya tingkat kesalahan dalam pembuatan laporan laba rugi, laporan arus kas, laporan order, dan laporan stok barang. Ketujuh, kesulitan dalam mengatur urutan produk mana saja yang harus didahulukan untuk dikerjakan agar dapat diselesaikan tepat waktu Penelitian ini bertujuan untuk mengusulkan pembuatan sistem informasi dalam mengintegrasikan data keuangan, data order, dan data stok. Sistem informasi tersebut diwujudkan dalam pembuatan aplikasi khusus yang telah disesuaikan dengan kebutuhan dan siklus bisnis pada Most Brothers. Aplikasi ini dapat menghasilkan laporan keuangan sederhana yang terdiri dari laba rugi dan arus kas. Terdapat pula laporan data order untuk menyelesaikan pesanan konsumen secara terstruktur dan tepat waktu. Serta, laporan data stok barang untuk mengetahui jumlah bahan baku produksi yang tersedia. Pada aplikasi ini, hak akes penuh penggunaan aplikasi ini dimiliki oleh pemilik ( $a d m i n)$ sedangkan karyawan yang ditunjuk sebagai user memiliki hak akses terbatas. Tentunya, dengan adanya aplikasi ini diharapkan bahwa pemilik dapat memperoleh data secara cepat dan akurat dalam mengambil keputusan.

\section{DAFTAR PUSTAKA}

Alim, Syahirul and Haryanto. 2008. Perancangan dan Pembuatan Analisa Sistem Informasi Pemasaran Pada PT. Andhika Dian Utama Surabaya (LPG Filling Plant) Berbasis Web. Jurnal Narotama Collection, Fakultas Ilmu Komputer Universitas Narotama Surabaya.

Asfi, Marsani and Ratna Purnama S. 2010. Sistem Penunjang Keputusan Seleksi Mahasiswa Berprestasi Menggunakan Metode AHP (Studi Kasus: STMIK CIC Cirebon). Jurnal Informatika, Vol. 6, No. 2. Page: 131-144

Daud, Rochmawati and Valeria Mimosa Windana. 2014. Pengembangan Sistem Informasi Akuntansi Penjualan dan Penerimaan Kas Berbasis Komputer pada Perusahaan 
Kecil (Studi Kasus pada PT.

Trust Technology). Jurnal

Manajemen dan Bisnis

Sriwijaya, Vol. 12, No.1.

Hastoni and David H. M. Hasibuan.

2007. Analisis dan

perancangan Sistem Penjualan

dan Piutang dalam Rangka

Meningkatkan Efisiensi dan Efektifitas pada PT. Multi

Kingindo Sarana. Jurnal Ilmiah

Kesatuan, Vol. 9, No. 2.

Indrajani. 2008. Analisis dan

Perancangan Sistem Informasi

Akuntansi

PembiayaanKonsumen.

Konferensi Nasional Sistem dan Informatika, KNS \& 108054.

Kurniawan, Adi and Mario. 2013. Sistem Informasi Penjualan Berbasis Web Pada Berkat Motor. Jurnal Jurusan Sistem Informasi STMIK GI MDP

Pratama, Devin and Toto Sugiharto. 2014. Analisis dan Perancangan Sistem Informasi Akuntansi Penggajian pada PT. Karya Murni Inda. Prosiding Seminar Ilmiah Nasional Komputer dan Sistem Intelijen (KOMMIT 2014), Vol. 8, ISSN : 2302-3740.
Pressman, Roger S. 2003. Rekayasa

Praktis Lunak Pendekatan Praktisi (Buku I). Andi, Yogyakarta.

Purnomo, Ignasius $\mathrm{B}$ and Toto Sugiharto. 2002.

Pengembangan Sistem Informasi Penjualan Sebagai Alat Penunjang Keputusan Pemasaran (Studi Kasus di PT. $X)$. Jurnal Ekonomi dan Bisnis No. 2, Jilid 7.

Reddy, G. Satyanarayana, Rallabandi S, Srikanth R. R, Vuda S. R. 2009. Management Information System to Help Managers for Providing Decision Making in an Organization. International Journal of Reviews in Computing. E-ISSN: 20763336.

Srivastava, Kingshuk, P.S.V.S.Sridhar, and Ankit Dehwal. 2012. Data Integration Challenges and Solutions: A Study. International Journal of Advanced Research in Computer Science and Software Engineering. Vol.2, No. 7. ISSN: 2277128X.

Undang-Undang Republik Indonesia No. 20 Tahun 2008 tentang Usaha Mikro, Kecil dan Menengah. 